\title{
ANALISIS MENGENAI KEBERADAAN RUANG PUBLIK TERPADU RAMAH ANAK DI LOKASI KOMPLEKS PERUMAHAN OBJEK STUDI: RPTRA NUSA INDAH, JAKARTA BARAT
}

\author{
Agnatasya Listianti Mustaram ${ }^{1}$ \\ ${ }^{1}$ Program Studi Sarjana Arsitektur, Universitas Tarumanagara Jakarta \\ Surel: agnatasyal@ft.untar.ac.id
}

\begin{abstract}
Since its opening on October 10, 2017, Taman Nusa Indah located within the BPPT Housing Complex area has officially changed into the RPTRA Nusa Indah. Previously Taman Nusa Indah was only an ordinary Green Open Space (RTH) located inside a housing complex, but has now undergone many upgrades and added facilities. It is this change that invites residents outside the housing complex to visit, and as a result at certain times the Nusa Indah RPTRA becomes very crowded. Residents of the housing complex directly adjacent to the RPTRA area are those who have experienced significant changes since Taman Nusa Indah has changed to RPTRA. The effects that occur due to the presence of RPTRA in this housing complex will be discussed in this study. This paper was made based on qualitative research method, namely by field observation and holding direct interviews. The result of this paper is in the form of a proposal for the provision of additional space within the Nusa Indah RPTRA area to overcome the various impacts of the emergence of RPTRA in the housing complex area, in this case the BPPT Complex.
\end{abstract}

Keywords: housing, child friendly, RPTRA, open public space

\begin{abstract}
ABSTRAK
Semenjak diresmikan tanggal 10 Oktober 2017, Taman Nusa Indah yang terletak di dalam kawasan Kompleks Perumahan BPPT resmi berganti menjadi RPTRA Nusa Indah. Sebelumnya Taman Nusa Indah hanyalah sebuah Ruang Terbuka Hijau (RTH) biasa yang berlokasi di dalam kompleks perumahan, namun kini telah mengalami banyak pembaruan dan tambahan fasilitas. Perubahan inilah yang mengundang warga di luar kompleks perumahan datang berkunjung, akibatnya pada waktu-waktu tertentu RPTRA Nusa Indah menjadi sangat ramai. Warga kompleks perumahan yang berbatasan langsung dengan kawasan RPTRA merupakan pihak yang mengalami perubahan signifikan semenjak Taman Nusa Indah berubah menjadi RPTRA. Efek yang terjadi akibat keberadaan RPTRA di dalam kompleks perumahan inilah yang akan dibahas dalam penelitian ini. Tulisan ini dibuat berdasarkan metode penelitian kualitatif, yaitu dengan observasi ke lapangan sekaligus mengadakan wawancara langsung. Hasil dari penulisan makalah ini adalah berupa usulan pengadaan ruang tambahan di dalam wilayah RPTRA Nusa Indah untuk mengatasi berbagai dampak dari munculnya RPTRA dalam wilayah kompleks perumahan, dalam hal ini Kompleks BPPT.
\end{abstract}

Kata kunci: perumahan, ramah anak, RPTRA, ruang publik terbuka

\section{PENDAHULUAN}

\section{Latar Belakang}

Pemerintah telah mengatur keberadaan Ruang Terbuka Hijau (RTH) dalam UU no. 26 Tahun 2007. Termasuk di dalamnya adalah pengaturan mengenai Ruang Terbuka Hijau di wilayah perkotaan. Sebagai ibukota Indonesia, Jakarta termasuk kota yang terus membenahi diri dengan kesesuaian mengenai penataan ruang yang telah ditentukan oleh pemerintah melalui Undang Undang. Pada perjalanannya, Jakarta terus berkembang menjadi kota yang layak untuk anak 
(Mungkasa, 2017). Lahirnya Ruang Publik Terpadu Ramah Anak (RPTRA) di beberapa wilayah Jakarta merupakan salah satu upaya untuk mencapai cita-cita tersebut.

RPTRA merupakan sebuah tempat yang menjadikan kata 'anak' menjadi istimewa, walaupun aktifitas di dalamnya kerap melibatkan orang dewasa. Untuk menciptakan ruang publik yang ramah anak, maka perlu digaris bawahi aktifitas utama anak, yaitu bermain. Dengan demikian sebuah RPTRA yang baik hendaknya memperhatikan hal tersebut, tempat ini minimal harus dapat memenuhi kebutuhan bermain anak.

Bermain bagi anak-anak dapat didefinisikan sebagai sebuah tempat, yaitu ruang yang aman bagi anak-anak untuk belajar tentang apapun di dunia (Nitecki, et al, 2016), dan juga sebuah wadah untuk bereksplorasi. Ruang yang terdesain untuk anak, harus memperhatikan kepentingankepentingan anak dan hendaknya tidak berbahaya bagi anak. Untuk menciptakan sesuatu yang tidak berbahaya bagi anak, selain aspek fisik keruangan, harus diperhatikan juga aspek sosial. Lingkungan sosial adalah kunci untuk menciptakan sebuah ruang yang penuh energi sekaligus aman. (Krishnamurthy et al, 2018).

\section{Transformasi Ruang Terbuka Publik}

Setelah ditransformasikan menjadi RPTRA, taman Nusa Indah mengalami penambahan fasilitas yang menambah daya tariknya sebagai ruang publik. Elemen natural pada Taman Nusa Indah dahulu telah berhasil menarik perhatian anak-anak dengan menjadikannya wahana permainan alami. Ketika berubah menjadi RPTRA, terjadi penambahan fasilitas pendukung dan wahana permainan yang lebih terdesain sehingga semakin mengundang orang untuk datang dan tertarik untuk 'bermain' di dalamnya. Hal ini mendukung teori dari Michael Laris dalam tulisannya, Designing for Play, yang mengatakan bahwa jika didukung oleh lingkungan urban yang terkontrol, maka mainan buatan (industrially manufactured play items) dapat memberikan pengalaman bermain yang lebih baik daripada permainan yang murni berasal dari alam (Dudek, 2005).

Berbicara mengenai RPTRA, maka konsep ruang terbuka terpadu menjadi bahasan yang dititik beratkan. Terpadu berarti tidak hanya memberikan ruang kosong pada lahan terbuka, namun dilengkapi dengan fasilitas yang memadai. Di DKI Jakarta, mengenai RPTRA bahkan dikhususkan tim pembangunan dan pemeliharaannya yang tertuang dalam Keputusan Gubernur DKI Jakarta no. 349 tahun 2015 (Mungkasa, 2017). Dalam penetapan lokasi RPTRA tentu saja tim ini telah mengaji dengan lebih detail dan komperehensif tentang dampak pembangunan RPTRA di lokasi tertentu.

Walaupun menempati lokasi yang sama, Taman Nusa Indah dan RPTRA memiliki pengalaman ruang yang berbeda. Karena sesungguhnya ruang bukanlah hanya sekadar kompleksitas merubah titik pandang atau perasaan, melainkan juga berkaitan dengan keberlangsungan hidup dan penghargaan kebudayaan (Tuan, 1981).

\section{Lokasi dan Tingkat Kepadatan}

Pada lokasi perumahan Kompleks BPPT, keberadaan RPTRA mengalami dampak yang signifikan terhadap tingkat kunjungan warga, baik warga yang tinggal pada kompleks perumahan tersebut, maupun warga sekitar kompleks. Secara lokasi, kompleks BPPT merupakan wilayah kompleks perumahan yang berbatasan langsung dengan kompleks perumahan lain, yaitu Taman Aries. Secara wilayah, luasan Kompleks BPPT jika dilihat dari bentukan diagram (Gambar 1) hanya sepertiga dari Taman Aries. Di tengah-tengah kedua kompleks perumahan 
tersebut terdapat wilayah perantara yaitu sebuah perkampungan padat penduduk. Inilah yang menyebabkan walaupun terletak di dalam kompleks BPPT, namun pengunjung RPTRA tidak hanya berasal dari dalam wilayah Kompleks BPPT saja, melainkan sebagian dari warga perkampungan di wilayah perantara antara Taman Aries dengan Kompleks BPPT , dan juga warga Taman Aries yang terletak berdekatan wilayahnya dengan Kompleks BPPT. Ketidakadaan penghalang akses di antara wilayah ini juga menyebabkan tidak adanya batasan yang jelas mengenai siapa saja yang dapat masuk ke wilayah kompleks BPPT dan siapa yang tidak. Dengan demikian, wilayah Kompleks BPPT menjadi semakin padat dengan keberadaan warga di luar yang datang sebagai pengunjung RPTRA.

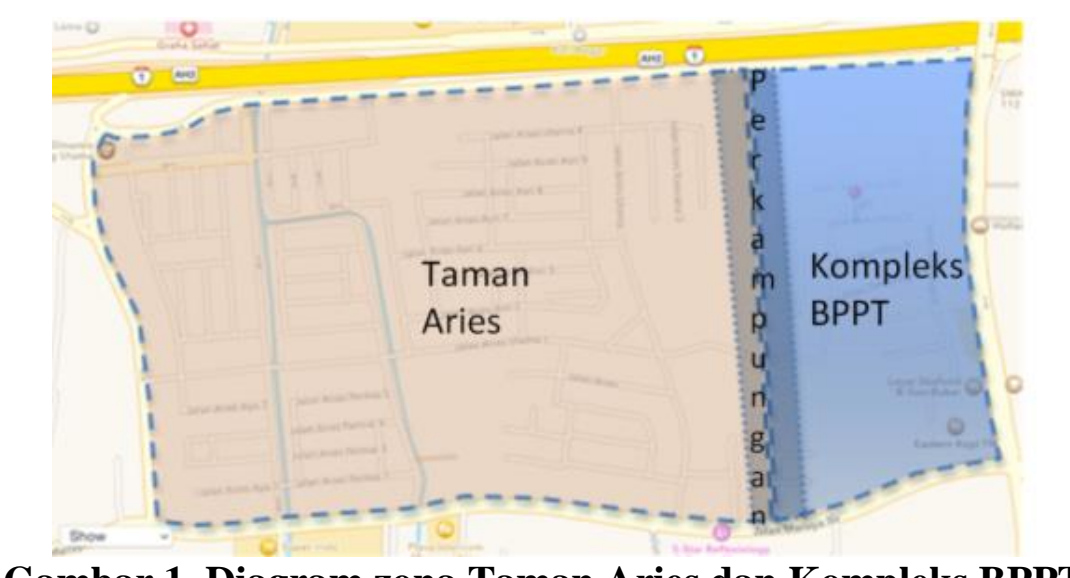

Gambar 1. Diagram zona Taman Aries dan Kompleks BPPT

Sumber: disunting dari googlemaps.com

Perubahan juga terjadi dalam hal menjamurnya pedagang di lokasi RPTRA. Pedagang kaki lima yang berjualan makanan, mainan anak, sampai sewa kereta kuda keliling datang menjamuri wilayah RPTRA. Padahal sebelumnya, para pedagang tidak berdagang di wilayah tersebut. Sebetulnya sebelum RPTRA ini dibangun hal ini sudah dapat diprediksi oleh Tim pembangunan dan pemeliharaan RPTRA, karena pedagang kaki lima hampir dapat dipastikan selalu hadir di setiap keramaian yang melahirkan konsentrasi massa.

Manusia dapat memberikan persepsi secara aktif dan prediktif terhadap pola-pola keteraturan yang terjadi (Lawson, 2001), antusias warga dan datangnya para pedagang kaki lima di lokasi keramaian merupakan hal yang berulang dan terbaca pola dan ritmenya. Maka sebenarnya hal tersebut merupakan hal yang sepatutnya terprediksi. Ketika hal ini terjadi seharusnya pihak yang berwenang telah siap dengan solusi permasalahan.

\section{Keamanan, Sampah, dan Pemeliharaan}

Taman Nusa Indah yang sebelum berubah menjadi RPTRA hanya digunakan warga Kompleks BPPT saja, kini didatangi oleh masyarakat luar yang asing bagi warga. Hal ini merupakan perubahan yang cukup besar dan patut diwaspadai dari sisi keamanan. Banyak warga masyarakat yang tidak saling mengenal berdatangan, belum lagi sebagian pengunjung RPTRA memarkirkan kendaraannya di sisi-sisi jalan yang berhubungan langsung dengan rumah penduduk. Walaupun secara teori kendaraan yang terparkir di sisi jalan akan meningkatkan kehati-hatian pengemudi di jalan yang secara tidak langsung menjadi kontrol kecepatan berkendara dan cenderung aman untuk zona anak kecil (Krishnamurthy et al, 2018), hal ini cukup mengganggu akses masuk keluar penghuni rumah dan tak jarang menimbulkan kecurigaan penghuni.

Selain dari sisi keamanan, masalah sampah adalah juga yang perlu digarisbawahi. Meskipun telah disediakan tempat sampah di dalam wilayah RPTRA, banyak pengunjung yang tidak membuang sampah pada tempatnya. Akibatnya sampah berserakan di dalam dan luar RPTRA. 
Banyak yang mengira bahwa permasalahan pemeliharaan ini adalah masalah yang biasa saja, namun sesungguhnya hal ini mempengaruhi hubungan anak dengan ruang terbuka publik. Anakanak biasanya selalu terbuka dan vokal terhadap lingkungan lokalnya. Ketidak pedulian orang lain terhadap ruang terbuka publik, seperti buang sampah sembarangan, perundungan, perusakan, dan lain-lain biasanya melahirkan persepsi negatif anak (Thomas et al, 2004).

\section{Tujuan Penelitian}

Penelitian ini bertujuan untuk menganalisis mengenai dampak yang terjadi (positif dan negatif) ketika Ruang Publik Terpadu Ramah Anak berada di dalam sebuah kompleks perumahan, dalam hal ini Kompleks BPPT, kelurahan Meruya Utara, kecamatan Kembangan, Jakarta Barat. Serta memberikan solusi dari persoalan yang muncul (jika ada).

\section{METODE PENELITIAN}

Penelitian ini dilakukan berdasarkan observasi langsung ke lapangan, yaitu RPTRA Nusa Indah di Kompleks BPPT, Jl. Teknologi VIII, Meruya Utara, Kembangan, Jakarta Barat. Pengamatan dilakukan selama 14 hari (dua minggu) dimulai pada hari Senin, 15 Oktober 2018 sampai dengan hari Minggu, 28 Oktober 2018.

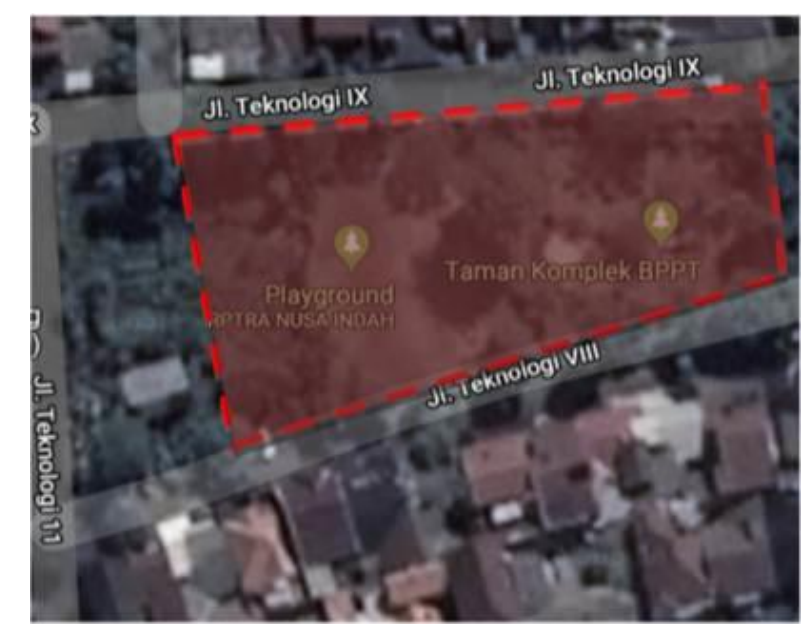

Gambar 2. Lokasi RPTRA Nusa Indah

Daerah yang dikelilingi garis putus-putus adalah wilayah RPTRA

Sumber: disunting dari googlemaps.com

RPTRA Nusa Indah secara garis besar terdiri dari Area Hijau, Jogging track, area lapangan olahraga, area indoor dan area servis (termasuk ruang baca, pengurus, dan toilet), area playground (terdiri dari perangkat main anak-anak seperti ayunan, perosotan, dan lain lain), selain itu RPTRA ini juga dilengkapi dengan area kolam berukuran kecil dan juga area tribun. 


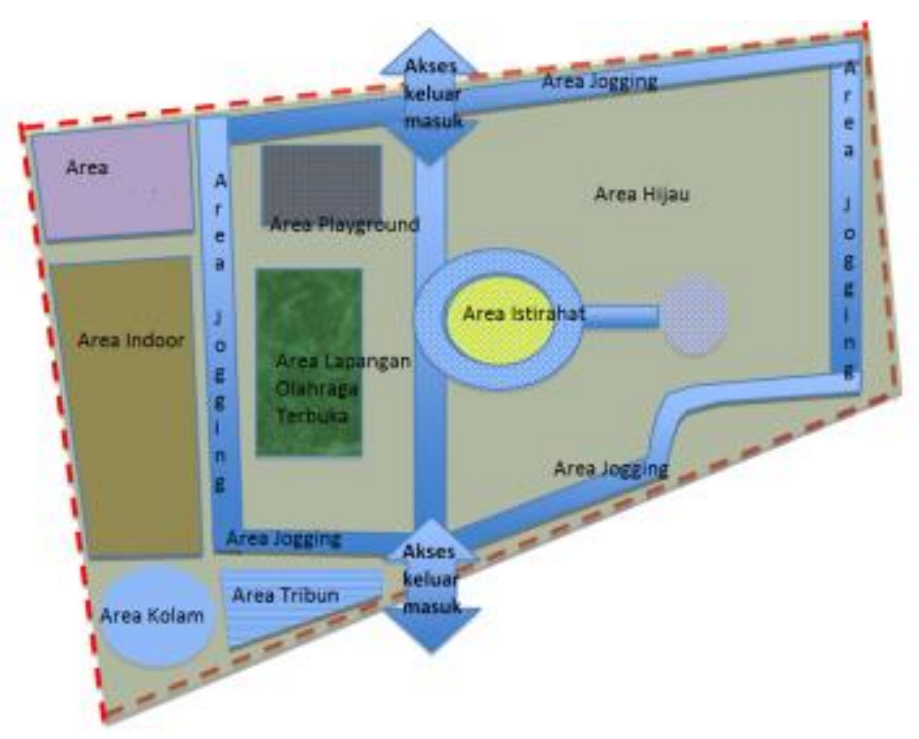

Gambar 3. Pola pembagian Ruang RPTRA Nusa Indah

Sumber: disunting dari googlemaps.com

Selain observasi langsung ke lapangan, wawancara dilakukan dengan empat orang warga yang terletak di Jl. Teknologi IX, yaitu jalan utama yang berbatasan langsung dengan RPTRA. Lokasi akses masuk-keluar di RPTRA ini terdiri dari dua pintu, yaitu pintu utama yang terletak di Jl. Teknologi VIII dan pintu lain di lokasi Jl. Teknologi IX. Walaupun letak pintu utama di Jl. Teknologi VIII, namun ukuran Jalan di JL. Teknologi IX lebih lebar, sehingga yang lebih banyak digunakan adalah pintu masuk di Jl. Teknologi IX. Pada awalnya, pintu masuk yang digunakan hanya yang terletak di Jl. Teknologi VIII, sedangkan pintu masuk yang terletak di Jl. Teknologi IX dikunci oleh petugas dan hanya dapat digunakan di waktu-waktu tertentu saja. Namun pada perjalanannya akhirnya pintu yang terletak di Jl. Teknologi IX juga dibuka dan dapat digunakan untuk umum.

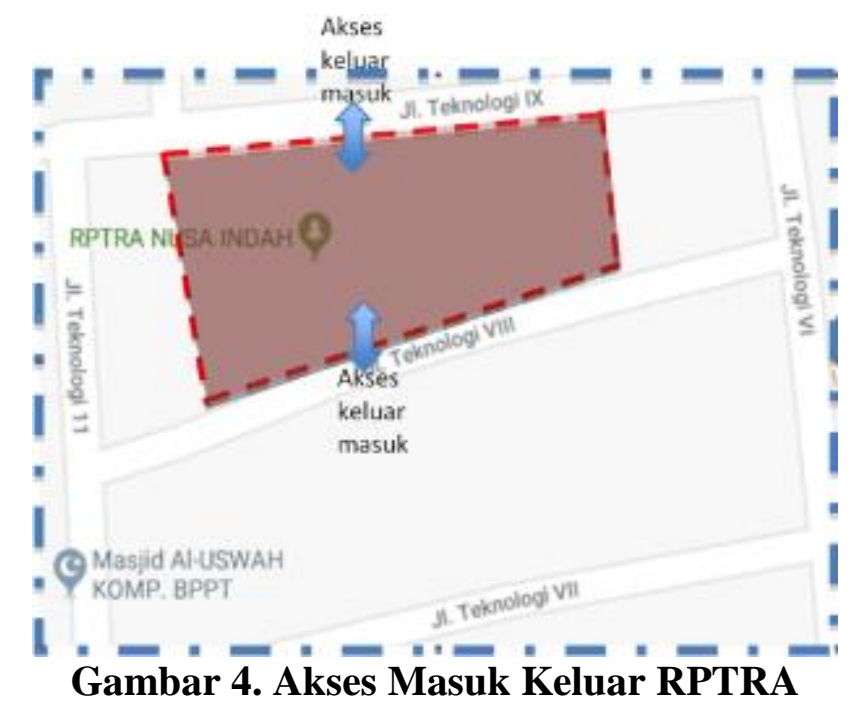

Sumber: disunting dari googlemaps.com

\section{HASIL DAN PEMBAHASAN Observasi Lapangan}


RPTRA Nusa Indah terdiri dari beberapa bagian yang saling terintegrasi satu dengan yang lain. Beberapa zona memang dikhususkan untuk anak, dan sebagian lagi digunakan untuk umum.

Area playground menempati wilayah yang paling dekat dengan pintu masuk yang terletak di sisi Jl. Teknologi IX. Area ini cukup aman bagi anak dengan alas lantai yang dilapisi bahan empuk dan dilengkapi dengan permainan berkualitas seperti perosotan dan ayunan. Wilayah ini juga menjadi daya tarik RPTRA Nusa Indah sehingga selalu ramai dan beberapa kali terlihat anak kecil mengantri menunggu giliran bermain.
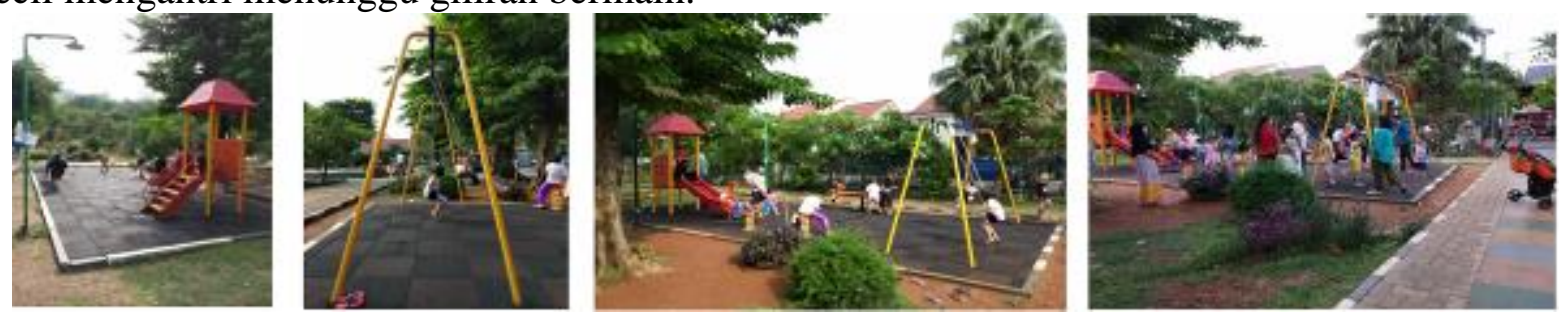

Gambar 5. Area Playground RPTRA Nusa Indah

(dari kiri ke kanan: wahana perosotan, wahana ayunan, sisi samping 1, sisi samping 2)

*Catatan: Letak Zona Playground dapat dilihat pada Gambar 3

Sumber: Dokumentasi Pribadi, 2018

Selain area playground, area yang juga sering digunakan adalah jogging track. Di pagi hari wilayah ini dipenuhi oleh masyarakat dari mulai balita sampai usia lanjut. Selain untuk jogging, lintasan ini juga digunakan untuk berjalan kaki biasa. Bahkan tak jarang beberapa anak kecil menggunakannya untuk area bersepeda.

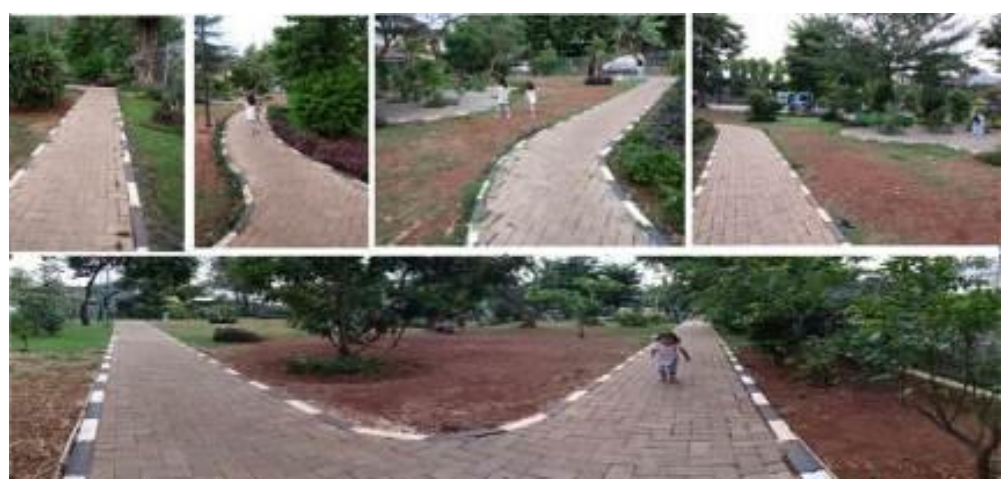

Gambar 6. Area Jogging dan Berjalan Kaki

*Catatan: Letak Area Jogging dan berjalan kaki dapat dilihat pada Gambar 3

Sumber: Dokumentasi Pribadi, 2018

Salah satu bagian dari RPTRA Nusa Indah yang selalu disibukkan dengan aktifitas adalah bagian lapangan basket. Walaupun berbentuk lapangan basket, namun sejatinya lapangan ini digunakan oleh berbagai jenis olahraga. Di hari Selasa dan Jumat, lapangan ini digunakan untuk kegiatan senam dari ibu-ibu PKK, lalu di hari tertentu ada pelatihan bela diri anak-anak, di hari lain lagi terdapat pelatihan futsal, dan lain sebagainya. Di dekat lapangan ini juga terdapat area refleksi kaki, yaitu sebuah daerah perkerasan yang terbuat dari bebatuan dan dapat diinjakkan kaki. 

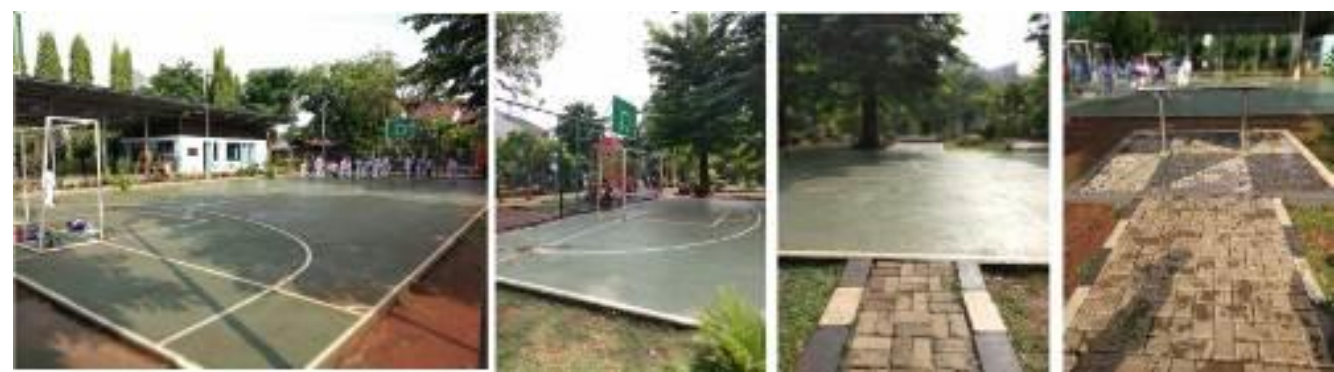

Gambar 7. Area Lapangan Olahraga dan Refleksi

(dari kiri ke kanan: lapangan basket dengan gawang, ring basket, jalan menuju area refleksi, area refleksi)

*Catatan: Letak Zona Lapangan Basket (Lapangan Olahraga Terbuka) dan Area Refleksi (Area Istirahat) dapat dilihat pada Gambar 3

Sumber: Dokumentasi Pribadi, 2018

Area lain yang terdapat pada RPTRA Nusa Indah ini adalah daerah Indoor, di mana area ini merupakan semacam kantor dan juga ruang servis. Tempat ini juga beberapa kali digunakan sebagai tempat penyuluhan kesehatan dan imunisasi. Toilet juga terdapat di area ini. Selain itu terdapat kebun mini yang dikelola oleh pengurus.
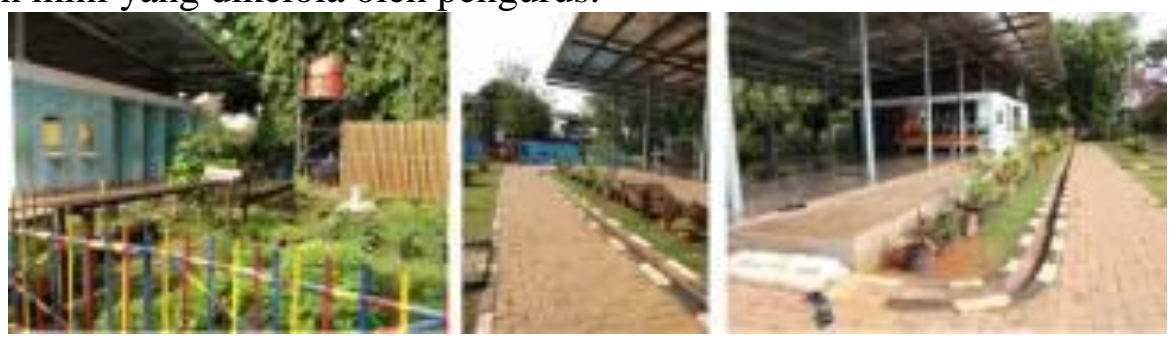

Gambar 8. Area Indoor dan Servis

(dari kiri ke kanan: toilet yang menghadap kebun mini, teras sisi kanan, teras sisi depan)

* Catatan: Letak Zona Indoor dapat dilihat pada Gambar 3

Sumber: Dokumentasi Pribadi, 2018

Berdasarkan observasi langsung di lapangan, RPTRA paling banyak dikunjungi pada pagi dan sore hari. Keadaan pengunjung juga berbeda di hari kerja (hari Senin sampai dengan Jumat) dengan di hari libur (hari Sabtu dan Minggu). Jika di hari kerja RPTRA hanya dikunjungi di pagi hari, sepi di siang hari dan ramai di sore hari, maka tidak demikian di akhir pekan. RPTRA sudah ramai pengunjung sejak pagi hingga ke sore hari tanpa jeda di siang hari. Bahkan tak jarang dipenuhi beberapa anak muda hingga malam hari. Selain kegiatan setiap hari, terdapat juga kegiatan khusus yang berlangsung setiap hari Selasa dan Jumat di mana terdapat kegiatan senam bersama Ibu-ibu PKK dengan instruktur khusus.

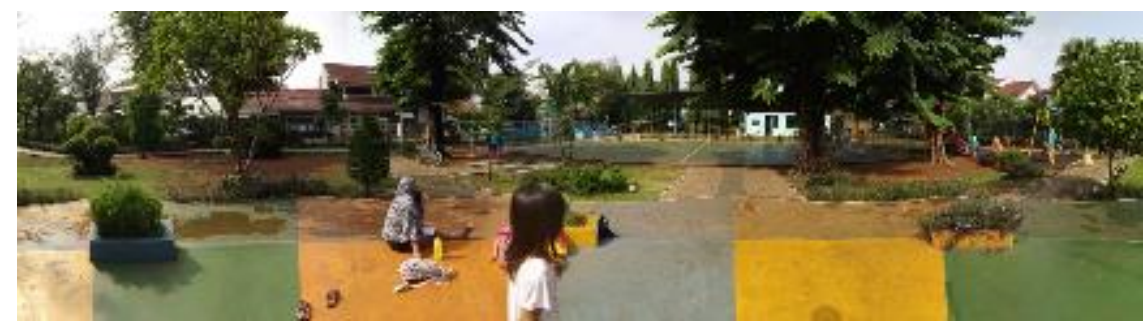

Gambar 9. RPTRA Nusa Indah dari sudut Jl. Teknologi VI

Sumber: Dokumentasi Pribadi, 2018 
Gambar di atas di ambil ketika siang hari menjelang sore, di mana belum banyak orang yang datang berkunjung. Secara garis besar, melalui pengamatan rata-rata selama dua minggu, prosentase pengunjung yang datang dapat dilihat dari tabel berikut:

Tabel 1. Presentase Pengunjung

\begin{tabular}{llcc}
\hline & Waktu & Hari Kerja (\%) & Akhir Pekan (\%) \\
\hline \multirow{2}{*}{$\begin{array}{c}\text { Pagi } \\
\text { (06:00-12:00) }\end{array}$} & awal & 20 & 50 \\
\cline { 2 - 4 } & tengah & 10 & 70 \\
\hline \multirow{2}{*}{\begin{tabular}{l} 
Siang- \\
\multirow{2}{*}{$\begin{array}{c}\text { Sore } \\
\text { (12:00-18:00) }\end{array}$}
\end{tabular}} & awhir & 5 & 30 \\
\cline { 2 - 4 } & tengah & 2 & 5 \\
\hline \multirow{2}{*}{$\begin{array}{c}\text { Malam } \\
\text { (18:00-00:00) }\end{array}$} & akhir & 15 & 30 \\
\cline { 2 - 4 } & tengah & 90 & 90 \\
\hline
\end{tabular}

Sumber: Pengamatan Langsung di lokasi

RPTRA paling banyak dikunjungi orang ketika sore hari dan intensitas pengunjung pada akhir pekan lebih banyak daripada hari biasa. Hal ini dapat membuktikan bahwa RPTRA digunakan juga sebagai tempat rekreasi di akhir pekan. Dari wawancara di lapangan pada sore hari ditemukan juga bahwa 4 dari 6 orang pengunjung bukanlah penghuni Kompleks BPPT.

\section{Wawancara Penghuni}

Wawancara khusus dilaksanakan pada hari Minggu 28 Oktober 2018 dengan 4 orang responden, yaitu warga Jl. Teknologi IX. Wilayah ini dipilih karena merupakan jalan yang berhubungan langsung dengan akses keluar masuk RPTRA. Dan walaupun gerbang utama berlokasi di Jl. Teknologi VIII, namun lebih banyak warga yang menggunakan pintu yang terletak di Jl. Teknologi IX. Secara fisik, Jl. Teknologi IX berukuran lebih lebar daripada Jl. Teknologi VIII (Catatan: Keterangan letak jalan dapat dilihat pada Gambar 4).
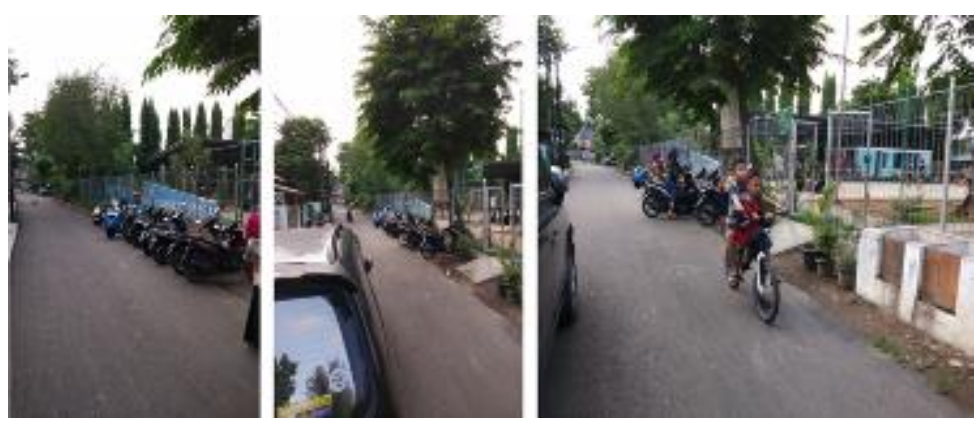

Gambar 10. Lokasi Jl. Teknologi VIII

(motor parkir sembarangan, mengambil ruas jalan umum)

Sumber: Dokumentasi Pribadi, 2018 


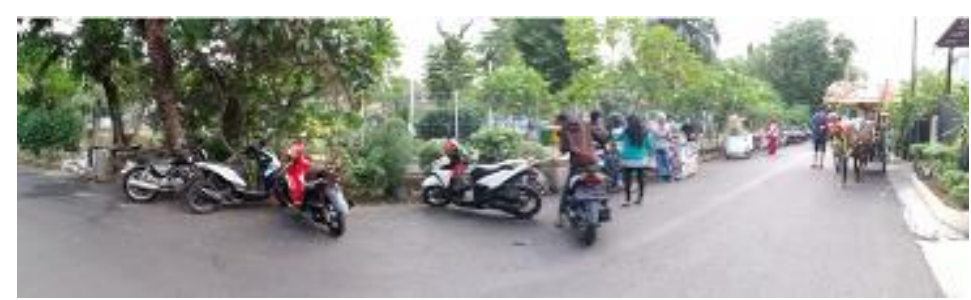

Gambar 11. Lokasi Jl. Teknologi IX

(motor parkir sembarangan, delman parkir di depan rumah warga)

Sumber: Dokumentasi Pribadi, 2018

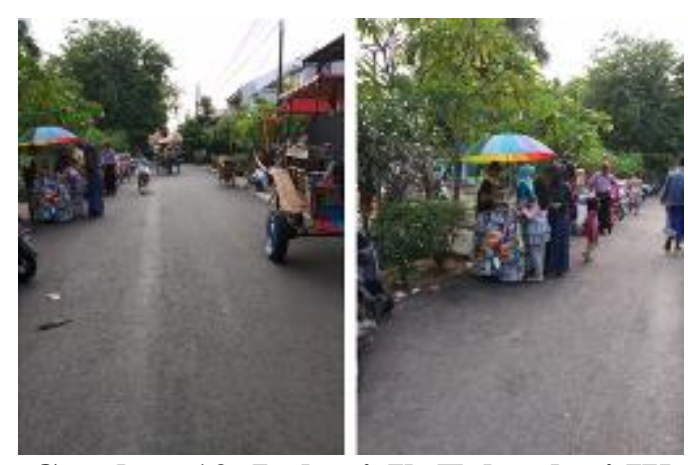

Gambar 12. Lokasi Jl. Teknologi IX

(kedatangan berbagai pedagang kaki lima dan delman di ruas jalan)

Sumber: Dokumentasi Pribadi, 2018

Warga yang terpilih sebagai responden adalah warga yang memiliki anak kecil, sudah menetap selama minimal 10 tahun di Kompleks BPPT, dan merupakan pengguna aktif RPTRA. Pertanyaan adalah mengenai perubahan dan dampak yang dirasakan langsung sejak Taman Nusa Indah berubah menjadi RPTRA. Mereka menggunakan RPTRA lebih sering untuk kebutuhan bermain anak, sedikit yang menggunakan untuk pribadi. 100\% responden menganggap sampah sebagai masalah yang krusial, selain juga masalah keamanan.

\section{Tabel 2. Wawancara Responden}

\begin{tabular}{|c|c|c|c|c|}
\hline & $\begin{array}{c}\text { Intensitas } \\
\text { Kunjungan }\end{array}$ & Lokasi Rumah & Dampak Positif & Dampak Negatif \\
\hline Responden A & $\begin{array}{l}\text { Kurang lebih } \\
\text { seminggu sekali } \\
\text { di sore hari di } \\
\text { akhir pekan }\end{array}$ & $\begin{array}{l}\text { Hoek antara Jl. } \\
\text { Teknologi IX dengan } \\
\text { Jl. Teknologi VI }\end{array}$ & $\begin{array}{l}\text {-Warga memiliki ruang } \\
\text { terbuka publik. } \\
\text {-Anak-anak memiliki } \\
\text { ruang bermain, } \\
\text { alternatif main gadget } \\
\text { di rumah. } \\
\text {-Beberapa program } \\
\text { berhasil meng-engage } \\
\text { warga. } \\
\text {-Ada ruang berkegiatan } \\
\text { untuk komunitas dan } \\
\text { Ibu-ibu PKK. }\end{array}$ & $\begin{array}{l}\text {-Karena berada di dalam } \\
\text { kompleks yang adalah } \\
\text { gated community, terdapat } \\
\text { beberapa keluhan soal } \\
\text { keamanan. } \\
\text {-Sampah berserakan. } \\
\text {-Kalau terlalu } \\
\text { dikomersilkan, bukan } \\
\text { kegiatan warga yang jalan. } \\
\text {-Desain terlalu top down, } \\
\text { kalau bisa bottom up lebih } \\
\text { bagus: melibatkan warga } \\
\text { juga sebaiknya. }\end{array}$ \\
\hline Responden B & $\begin{array}{l}\text { Hampir setiap } \\
\text { hari di sore hari. } \\
\text { Di akhir pekan } \\
\text { mulai dari pagi } \\
\text { hari. }\end{array}$ & $\begin{array}{l}\text { Bersebelahan dengan } \\
\text { Responden A }\end{array}$ & $\begin{array}{l}\text {-Bisa kenal satu sama } \\
\text { lain (penghuni lama } \\
\text { dengan penghuni baru). } \\
\text {-Anak sangat suka } \\
\text { bermain di RPTRA. }\end{array}$ & $\begin{array}{lrr}\text {-Tidak aman, banyak } \\
\text { warga yang bukan } \\
\text { penghuni. }\end{array}$ \\
\hline Responden C & $\begin{array}{l}\text { Hampir setiap } \\
\text { hari di sore hari. }\end{array}$ & $\begin{array}{l}\text { Tepat berada } \\
\text { tengah-tengah }\end{array}$ & $\begin{array}{l}\text {-Playgroundnya bagus, } \\
\text { kalau sepi bisa main }\end{array}$ & $\begin{array}{l}\text {-Sampah berserakan dari } \\
\text { pedagang kaki lima dan }\end{array}$ \\
\hline
\end{tabular}




\begin{tabular}{|c|c|c|c|c|}
\hline & $\begin{array}{l}\text { Di akhir pekan } \\
\text { mulai dari pagi } \\
\text { hari. }\end{array}$ & Teknologi IX & 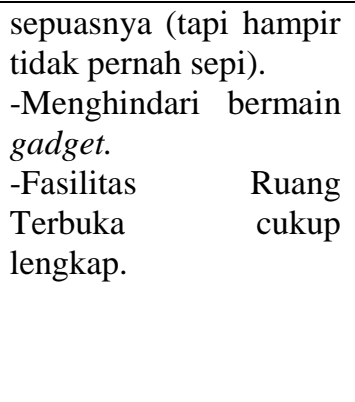 & $\begin{array}{l}\text { pembeli. } \\
\text {-Selalu ada yang } \\
\text { menghalangi jalan masuk } \\
\text { ke rumah (pernah tidak } \\
\text { bisa masuk rumah karena } \\
\text { ada motor pengunjung } \\
\text { tepat parkir di depan } \\
\text { pagar). } \\
\text {-Sangat bising, terutama } \\
\text { jika ada acara khusus. }\end{array}$ \\
\hline Responden D & $\begin{array}{l}\text { Seminggu kurang } \\
\text { lebih } 3 \mathrm{x}\end{array}$ & $\begin{array}{l}\text { Tepat berada di } \\
\text { depan akses masuk } \\
\text { keluar } \\
\text { berjarak } 1 \text { rumah } \\
\text { dengan Responden C }\end{array}$ & $\begin{array}{l}\text { Anak-anak } \\
\text { ruang terbuka. }\end{array}$ & $\begin{array}{l}\text {-Motor, pedagang, } \\
\text { delman, mobil, selalu } \\
\text { parkir persis di depan } \\
\text { rumah, } \\
\text { mengganggu. } \\
\text {-Sampah berserakan. } \\
\text {-Tidak ada privasi lagi. } \\
\text {-Orang tak dikenal yang } \\
\text { mencurigakan. }\end{array}$ \\
\hline
\end{tabular}

(Sumber: hasil olah data)

Dari hasil wawancara, setiap responden merasakan dampak positif keberadaan RPTRA untuk anak-anak mereka, sedangkan dampak negatif yang dirasakan berkisar masalah ke-tidak tertiban, sampah dan kurangnya keamanan. Untuk itu diperlukan sebuah solusi yang menjawab keresahan warga.

\section{KESIMPULAN DAN SARAN}

Dari uraian di atas, ditemukan adanya persoalan-persoalan yang muncul akibat keberadaan RPTRA di kompleks BPPT. Maka dapat disimpulkan bahwa keberadaan RPTRA memerlukan tindak lanjut berupa solusi baik yang bersifat fisik maupun yang strategis.

Solusi yang bersifat fisik di antaranya; penyediaan ruang tambahan di dalam lokasi yang berupa:

1. Zona yang dapat digunakan untuk kegiatan jual beli makanan, mainan, maupun benda lain yang wajar diperjualbelikan.

2. Lahan parkir roda dua

Sehingga kedua aktifitas (berdagang dan parkir) tidak mengambil ruas jalan yang mengganggu penghuni Kompleks BPPT.

Selain itu diperlukan juga sebuah solusi yang sifatnya strategis

- Petugas yang pro aktif mengatur ketertiban, peletakan sampah, dan terkait pemeliharaan lingkungan sekitar RPTRA.

- Kepengurusan dan kepengelolaan yang jelas dari RPTRA sehingga dapat menyalurkan aspirasi penghuni sekaligus tetap menyamankan pengunjung RPTRA

Penelitian lanjutan dapat membahas mengenai RPTRA Nusa Indah secara lebih mendalam lagi, misalnya dari segi ketepatan desain, warna dan pembagian area di dalamnya. Termasuk kemungkinan peletakan ruang tambahan yang diusulkan pada penelitian ini.

\section{Ucapan Terima Kasih (Acknowledgement)}

Kepada warga Kompleks BPPT, Pengunjung RPTRA Nusa Indah, dan Masyarakat sekitar yang bersedia memberikan informasi terkait penulisan penelitian ini. 


\section{REFERENSI}

---Undang Undang Republik Indonesia No. 26 Tahun 2007 tentang Ruang Terbuka Hijau.

Dudek, Mark. (2005). Children's Space. Architectural Press, Oxford.

Krishnamurthy, Sukanya. Steenhuis, Chris. Reijnders, Daniek. Stav, Tamy. (2018). ChildFriendly Urban Design: Observations on Public Space from Eindhoven (NL) and Jerusalem (IL). Eindhoven University of Technology Library, Eindhoven.

Lawson, Bryan. (2001). The Language of Space. Architectural Press, Oxford.

Mungkasa, Oswar. (2017). Grand Design Jakarta Menuju Kota Layak Anak 2018-2022. Desain Kota Layak Anak DKI Jakarta, House of Resource Center Yogyakarta, 28 November 2017.

Nitecki, Elena. Chung, Mi-Hyun. (2016). Play as Place: A Safe Space for Young Children to Learn About The World. The International Journal of Early Childhood Environmental Education, 4(1), 26-32.

Thomas, Gillian. Thompson, Guy. (2004). A Child's Place: Why Environment matters to Children. Green Alliance/DEMOS, London.

Tuan, Yi-Fu. (1981). Space and Place. University of Minnesota Press, Minneapolis.

prategangan) juga menimbulkan beberapa ketidak-konsistenan dari peraturan yang selama ini berlaku (Murdock, 1992). 